Vol. 9 (2000): 61-70.

\title{
Phosphorus saturation of Finnish soils: evaluating an easy oxalate extraction method
}

\author{
Risto Uusitalo, Hanna-Riikka Tuhkanen \\ Agricultural Research Centre of Finland, Resource Management Research, FIN-31600 Jokioinen, Finland, \\ e-mail: risto.uusitalo@mtt.fi
}

\begin{abstract}
The aim of this study was to test whether phosphorus saturation of surface sorption sites of (oxyhydr)oxides of aluminium ( $\mathrm{Al}$ ) and iron (Fe) in Finnish soils can be assessed using a single oxalate extraction and, if so, whether the results are closely related to the $\mathrm{P}$ forms likely to influence the $\mathrm{P}$ concentration in runoff waters. Ten soil samples with varying clay content and $\mathrm{P}$ status were studied. Desorption tests were conducted by submitting the soils sequentially to nine anion exchange resin (AER) extractions. Sorption of $\mathrm{P}$ was studied by shaking the soils in $\mathrm{P}$ standard solutions $(0-$ $250 \mathrm{ppm}$ ). Soil inorganic $\mathrm{P}$ was characterised by sequentially extracting $\mathrm{P}$ from the fractions assumed to be connected to $\mathrm{Al}$ and $\mathrm{Fe}$ compounds and present as the stable apatitic form. The desorption studies and the fractioning of inorganic P suggested that oxalate solution dissolves apatitic $\mathrm{P}$ and/or other relatively stable $\mathrm{P}$-bearing compounds, probably referring to the sum of inorganic $\mathrm{P}$ fractions rather than labile $P$. The amount of $P$ desorbed in the nine AER extractions was about $80-280 \mathrm{mg} / \mathrm{kg}$, whereas oxalate extracted about 490-1100 mg P/kg, which approximated the sum of the inorganic $\mathrm{P}$ fractions. Therefore, in soils high in apatitic $\mathrm{P}$, oxalate-extractable $\mathrm{P}$ does not seem to be a reliable measure of the $\mathrm{P}$ saturation of $\mathrm{Al}$ and $\mathrm{Fe}$ oxide surfaces that regulate the $\mathrm{P}$ concentration in soil solution and runoff water.
\end{abstract}

Key words: phosphorus desorption, phosphorus sorption, phosphorus saturation, oxalate extraction, environmental soil testing

\section{Introduction}

Poorly crystalline oxides of aluminium (Al) and iron $(\mathrm{Fe})$ have a high phosphorus $(\mathrm{P})$ retention capacity and are thus regarded as important regulators of labile P in non-alkaline soils (Lopez-
Hernandez and Burnham 1974, Mattingly 1975). Desorption/sorption reactions on mineral surfaces are considered to occur within minutes to hours, whereafter $\mathrm{P}$ is converted, by diffusioncontrolled migration, to more stable $\mathrm{P}$ compounds (Froelich 1988). The dissolution of sparsely soluble $\mathrm{P}$ forms and the transformation 


\section{AGRICULTURAL AND FOOD SCIENCE IN FINLAND}

\section{Uusitalo, R. \& Tuhkanen, H.-R. Phosphorus saturation of Finnish soils}

of labile P into stable P-bearing compounds may continue over a period of several days to months, even years.

Phosphorus desorbs more easily when $\mathrm{Al}$ and Fe oxides in soil are highly saturated with P. Phosphorus saturation (PS) is thus an important factor controlling, among other things, the concentration of dissolved $\mathrm{P}$ in runoff. One way to assess PS is to relate the abundance of oxalateextractable $\mathrm{P}$ to that of oxalate-extractable $\mathrm{Al}$ and $\mathrm{Fe}$. The degree of $\mathrm{P}$ saturation can be calculated as: $\operatorname{DPS}(\%)=100 \times \mathrm{P}_{\text {ox }} /\left(0.5 \times\left(\mathrm{Al}_{\text {ox }}+\mathrm{Fe}_{\mathrm{ox}}\right)\right)$, where all concentrations are expressed as $\mathrm{mmol} /$ $\mathrm{kg}$ (see Lookman et al. 1995). The denominator represents the $\mathrm{P}$ sorption capacity of soil. Since not all oxalate-extractable $\mathrm{Al}$ and $\mathrm{Fe}$ sorb $\mathrm{P}$, i.e. oxalate may also dissolve $\mathrm{Al}$ and Fe from crystalline oxides and other minerals (Reyes and Torrent 1997), a correction for "active" Al and Fe concentrations is used. Lookman et al. (1995) used a value of 0.5 as the correction term, calculated as the mean of values reported earlier (see Lookman et al. 1995). The same value was then adopted by Yli-Halla et al. (1998) and Turtola and Yli-Halla (1999) for Finnish soils.

It is, however, uncertain whether the correction factor is the same for soils of different origin and occurring under different climatic conditions. Finnish soils are considered young, only 10000 years having passed since deglaciation and the start of soil formation. Soil formation involves aging, i.e., changes in the crystal structure, of (hydr)oxides; this in turn affects their chemical reactivity. Therefore, the correction for active $\mathrm{Al}$ and $\mathrm{Fe}$ in Finnish soils may differ from that in soils in regions where soil formation has proceeded further. Moreover, Finnish soils usually contain large amounts of apatitic $\mathrm{P}$ (Hartikainen 1979), which dissolves at low $\mathrm{pH}$. As discussed by Hartikainen (1979), the possibility that apatitic $\mathrm{P}$ will dissolve in oxalate extraction cannot be excluded, since the oxalate solution has a $\mathrm{pH}$ as low as 3.0.

If PS obtained by oxalate extraction is to be used in environmental soil testing, for instance, to explain the $\mathrm{P}$ concentration in runoff waters, the amount of labile $\mathrm{P}$, excluding slightly solu- ble P compounds (e.g. apatite), should be estimated. To relate the oxalate-extractable $P$ to different inorganic P pools, we determined the Chang \& Jackson P fractions (Chang and Jackson 1957, modified by Hartikainen 1979) and oxalate-extractable P for ten soils. Using P desorption and sorption tests, we assessed the concentration of labile $\mathrm{P}$, and estimated the correction term for "active" oxalate-extractable $\mathrm{Al}$ and $\mathrm{Fe}$ for these ten soils. We also prepared pure Al and $\mathrm{Fe}$ oxides and studied their $\mathrm{P}$ sorption capacity and the extractability of $\mathrm{Al}$ and $\mathrm{Fe}$ (by oxalate solution) to compare the relationship between $\mathrm{P}$ sorption and "active" $\mathrm{Al}$ and $\mathrm{Fe}$ in pure compounds and soils.

\section{Material and methods}

Ten soil samples from the Ap horizons of arable fields in southern and central Finland were selected for study. The soils, which had varying clay contents and P status, were the same as those studied by Yli-Halla (1993), who describes them in detail. A brief description of the soils is given here in Table 1.

Pure $\mathrm{Al}$ and $\mathrm{Fe}$ oxides were prepared from wastewater treatment chemicals, polyaluminium chloride (Kemwater PAX-18, Kemira Chemicals Ltd.) or ferric sulphate (PIX-115, the same manufacturer) and acid-washed quartz sand (QS). According to the manufacturer, Kemwater PAX18 contains $8.9 \% \mathrm{Al}$ and PIX-115 11.5\% Fe. To a 300 -g portion of QS, we added $150 \mathrm{~g}$ of $\mathrm{Al}$ or $\mathrm{Fe}$ chemical solution and mixed them thoroughly. We then added $250 \mathrm{ml}$ of $2.5 \mathrm{M} \mathrm{NH}_{4} \mathrm{OH}$ to the QS chemical suspension and left the mixture to stand overnight. Next day the materials were transferred to plastic PVC pipes $(15 \mathrm{~cm}$ long, $10 \mathrm{~cm}$ in diameter) with a nylon mesh screen attached to the bottom as a sieve, were thoroughly washed with deionised water and allowed to air-dry. The Al-coated QS is hereafter referred to as "Al-QS" and the Fe-coated QS as "Fe-QS". 
Vol. 9 (2000): 61-70.

Table 1. Selected properties of the soils studied.

\begin{tabular}{|c|c|c|c|c|c|c|c|}
\hline $\begin{array}{l}\text { Soil } \\
\text { number }\end{array}$ & $\begin{array}{c}\text { Clay } \\
(<2 \mu \mathrm{m})\end{array}$ & $\begin{array}{c}\text { Fine silt } \\
(2-20 \mu \mathrm{m})\end{array}$ & $\mathrm{C}$ & $\mathrm{pH}$ & AAAc-P & Olsen-P & AER-P \\
\hline & . & $-\%$ & 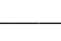 & & $\mathrm{mg} / \mathrm{l}$ & \multicolumn{2}{|c|}{$-\mathrm{mg} / \mathrm{kg}-$} \\
\hline 1 & 74 & 17 & 2.9 & 6.8 & 23.4 & 86.8 & 144 \\
\hline 2 & 67 & 24 & 7.7 & 5.3 & 7.5 & 42.8 & 90 \\
\hline 11 & 55 & 24 & 1.9 & 6.0 & 7.5 & 47.7 & 62 \\
\hline 13 & 51 & 31 & 3.2 & 6.7 & 17.4 & 79.9 & 125 \\
\hline 19 & 42 & 36 & 2.4 & 6.5 & 31.1 & 61.0 & 87 \\
\hline 30 & 25 & 37 & 3.1 & 6.2 & 20.1 & 69.7 & 85 \\
\hline 31 & 25 & 32 & 2.2 & 5.2 & 9.6 & 55.7 & 58 \\
\hline 33 & 24 & 46 & 2.3 & 6.3 & 30.4 & 84.9 & 116 \\
\hline 48 & 9 & 35 & 2.5 & 5.9 & 5.1 & 32.0 & 29 \\
\hline 54 & 6 & 15 & 1.7 & 6.3 & 20.7 & 62.2 & 66 \\
\hline
\end{tabular}

The soil numbers are the same as used by Yli-Halla (1993)

AAAc- $\mathrm{P}=\mathrm{P}$ extracted by $0.5 \mathrm{M}$ acid ammonium acetate, $\mathrm{pH} 4.65$ (Vuorinen and Mäkitie 1955)

Olsen-P = P extracted by $0.5 M \mathrm{NaHCO}_{3}, \mathrm{pH} 8.5$ (Kuo 1996)

AER-P $=\mathrm{P}$ extracted overnight $(18 \mathrm{~h})$ by anion exchange resin

\section{Phosphorus sorption and desorption}

Phosphorus sorption by the soils was studied by weighing $2 \mathrm{~g}$ of soil, Al-QS or Fe-QS, with duplicates, into centrifuge tubes to which were added $20 \mathrm{ml}$ of solutions with increasing $\mathrm{P}$ concentrations (0-250 ppm). The $\mathrm{P}$ solutions were made of $\mathrm{K}_{2} \mathrm{HPO}_{4}$ in deionised water. After shaking for $2 \mathrm{~h}$ on an orbital shaker (180 rpm), the solutions were passed through a $0.2 \mu \mathrm{m}$ Nuclepore filter, and the filtrates were analysed for P (Murphy and Riley 1962). The QSs shaken in the $250 \mathrm{ppm}$ $\mathrm{P}$ solution were then transferred to the filters with about $5-10 \mathrm{ml}$ of ethanol and allowed to air-dry before later extraction by oxalate.

To assess the amount of desorbable native soil $\mathrm{P}$, the untreated soil samples, with duplicates, were subsequently shaken with anion exchange resin (AER) using extraction times of up to 2 weeks. One gram of Dowex 1X8 strongly basic AER was enclosed in nylon mesh bags and converted to $\mathrm{HCO}_{3}$ form (Sibbesen 1978). For the extraction of $1 \mathrm{~g}$ of soil, one AER bag and $40 \mathrm{ml}$ of deionised water were added to screw-capped plastic tubes, and the suspension was shaken on an end-over-end shaker at a rate of $27 \mathrm{rpm}$. The
$P$ retained by the AER was then displaced by shaking the AER bags in $40 \mathrm{ml}$ of $0.5 \mathrm{M} \mathrm{NaCl}$ solution for $4 \mathrm{~h}$, after which the $\mathrm{NaCl}$ extract was analysed for P (Murphy and Riley 1962).

The shortest extraction time was $1 \mathrm{~h}$. The longer extractions were performed sequentially with nine AER bags, the used resin being replaced by a fresh AER bag after each shaking cycle. The first extraction in the sequence lasted for $18 \mathrm{~h}$, the following four extractions for 1 day $(24 \mathrm{~h})$, the next two extractions for 2 days (48 h), and the last two extractions for 3 days (72 h). The time taken by the last extraction thus totalled 354 hours, or about 2 weeks.

\section{Chang \& Jackson inorganic $P$ fractions}

Inorganic $\mathrm{P}$ fractions were sequentially extracted, with triplicates, by the Chang \& Jackson procedure as described by Hartikainen (1979). The purpose of the first extraction solution, $\mathrm{NH}_{4} \mathrm{Cl}$, is to wash away exchangeable $\mathrm{Ca}$. The second solution in the sequence, $0.5 \mathrm{M} \mathrm{NH}_{4} \mathrm{~F}(\mathrm{pH} \mathrm{8.5)}$, is assumed to extract Al-bound $\mathrm{P}$, and the third solution, 0.1 M NaOH, Fe-bound P. Stable ap- 
Uusitalo, R. \& Tuhkanen, H.-R. Phosphorus saturation of Finnish soils

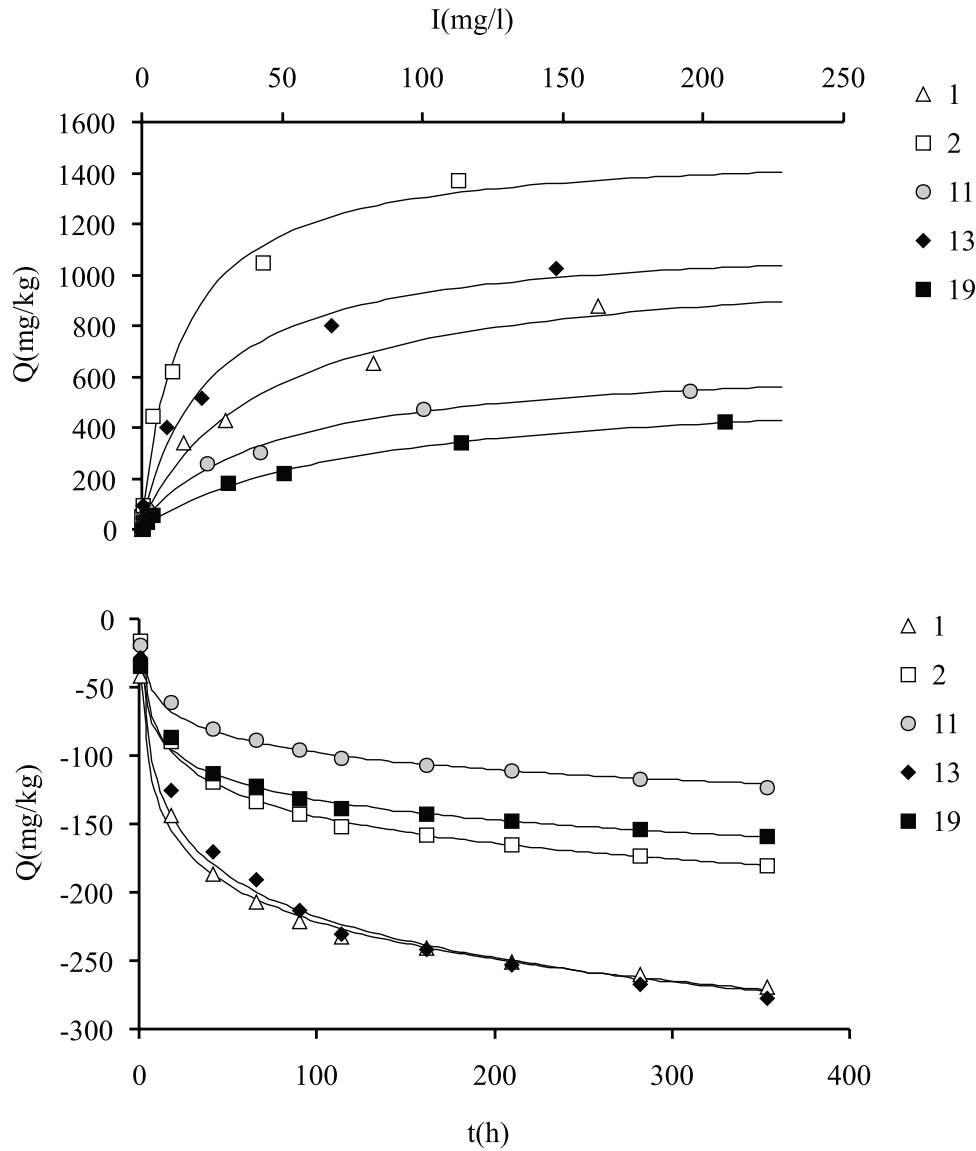

Fig. 1. Sorption (upper graph) and desorption (lower graph) curves for the clay soils ( $>30 \%$ clay-sized particles). The $\mathrm{x}$-axis of the sorption curves (I, mg/l) shows the solution $\mathrm{P}$ concentration after the 2-hour shaking in standard $\mathrm{P}$ solutions (0-250 ppm P). The $\mathrm{x}$-axis of the desorption curves is time $(\mathrm{t}, \mathrm{h})$. atitic (Ca-bound) $\mathrm{P}$ is assumed to be extractable by $0.5 \mathrm{~N} \mathrm{H}_{2} \mathrm{SO}_{4}$. The $\mathrm{P}$ concentration of the solutions was determined by a spectrophotometer (Shimadzu UV 120-02) using a wavelength of $882 \mathrm{~nm}$ after reduction of the phospho-molybdate complex with stannous chloride.

\section{Oxalate extraction}

One gram of soil (or Al-QS and Fe-QS shaken in a $250 \mathrm{ppm} P$ solution) was weighed into centrifuge tubes, with duplicates, and $50 \mathrm{ml}$ of 0.2 $\mathrm{M}$ ammonium oxalate-oxalic acid solution (Schwertmann 1964) was added. The extractant was made by mixing approximately $57 \% 0.2 \mathrm{M}$ ammonium oxalate $\left(\left(\mathrm{NH}_{4}\right)_{2} \mathrm{C}_{2} \mathrm{O}_{4} \cdot \mathrm{H}_{2} \mathrm{O}\right)$ and $43 \%$ $0.2 \mathrm{M}$ oxalic acid $\left(\mathrm{C}_{2} \mathrm{O}_{4} \cdot 2 \mathrm{H}_{2} \mathrm{O}\right)$ to give a final $\mathrm{pH}$ of 3.0.

The suspensions were shaken on an orbital shaker (180 rpm) for $4 \mathrm{~h}$ in the dark. The samples were then passed through (SchleicherSchuell blue ribbon) paper filters, and the filtrates analysed for $\mathrm{Al}$ and $\mathrm{Fe}$ by an inductively coupled plasma atomic emission spectrometer (ICP-AES; IRIS Advantage, Thermo Jarrel Ash). For $\mathrm{P}$ determination, $5 \mathrm{ml}$ of aliquot was pipetted into a $50 \mathrm{ml}$ bottle, and the oxalate was decomposed by adding $10 \mathrm{ml}$ of concentrated $\mathrm{HNO}_{3}$ and evaporating the solution on a hot plate to about $1 \mathrm{ml}$. Then $5 \mathrm{ml}$ of $1 \mathrm{M} \mathrm{HCl}$ was added into the bottle, which was filled up with deion- 
Vol. 9 (2000): 61-70.

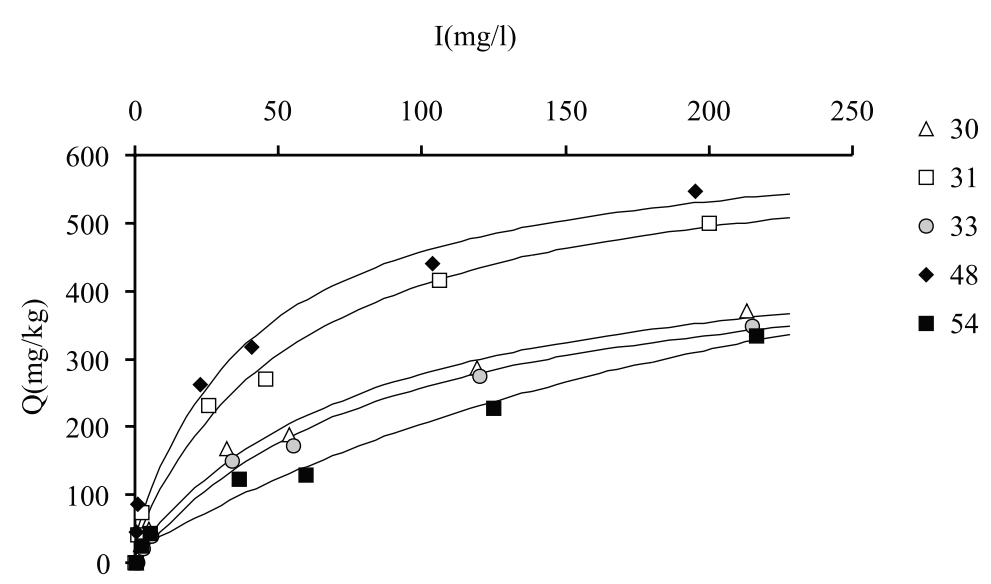

Fig. 2. Sorption (upper graph) and desorption (lower graph) curves for the non-clay soils ( $<30 \%$ claysized particles). The $\mathrm{x}$-axis of the sorption curves (I, mg/l) shows the solution $\mathrm{P}$ concentration after the 2-hour shaking in standard $\mathrm{P}$ solutions ( $(0-250 \mathrm{ppm} P)$. The $\mathrm{x}$-axis of the desorption curves is time $(t, h)$.

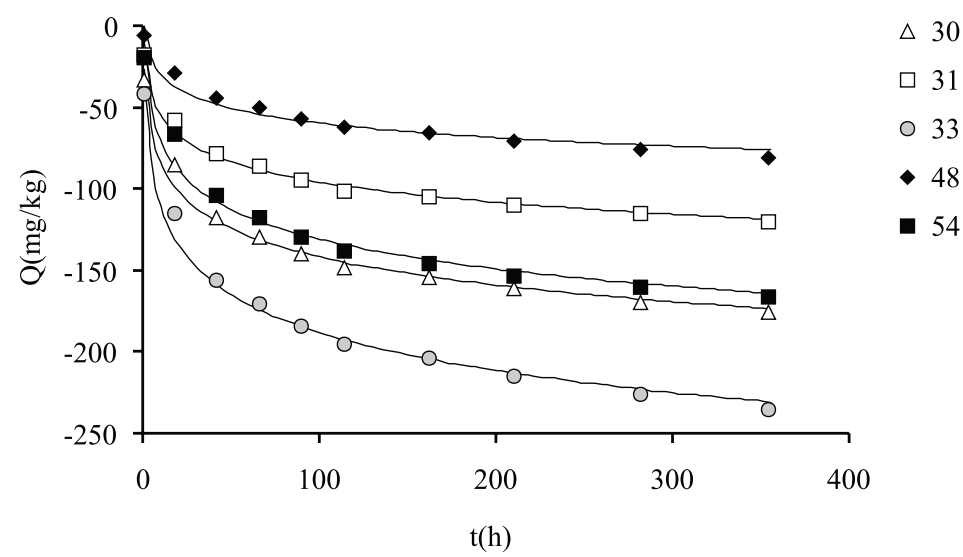

ised water. The $\mathrm{P}$ concentration of the solution was measured with a LaChat QC Analyzer by the method of Murphy and Riley (1962).

\section{Results}

The sorption curves were steep at the lowest $\mathrm{P}$ additions but levelled out as the amount of the added $P$ increased (Figs 1 and 2). The nearly linear part of the curves (up to concentrations of $10-50 \mathrm{ppm}$ of added P) indicated high-affinity sorption of P. Transition to lower affinity sorption took place at a bathing solution $\mathrm{P}$ concen- tration of $150 \mathrm{ppm}$ (of added $\mathrm{P}$ ) for the five most clayey soils (numbers 1-19; Fig. 1), and a P concentration of $75 \mathrm{ppm}$ for the five coarsest soils (numbers 30-54; Fig. 2), indicating that the surface-layer sorption sites were becoming saturated. Sorption of P in the most clayey soils (Fig. 1) greatly exceeded that in the coarse soils (Fig. 2).

The desorption curves revealed a pattern in which a rapid desorption phase is followed by one characterised by slow desorption (Figs 1 and 2 ). The nearly linear phase was assumed to involve desorption of $\mathrm{P}$ from $\mathrm{Al}$ and $\mathrm{Fe}$ (hydr)oxide surfaces that were sufficiently saturated to allow desorption when $\mathrm{P}$ is removed from the ambient solution by the AER. The slow reaction was 
Uusitalo, R. \& Tuhkanen, H.-R. Phosphorus saturation of Finnish soils

Table 2. Cumulative $\mathrm{P}$ desorption in 2-weeks' sequential AER extraction $(9 \times \mathrm{AER})$, and sorption of $\mathrm{P}$ by soils from 250 ppm standard P solution

\begin{tabular}{|c|c|c|}
\hline Soil number & $\begin{array}{r}\text { Desorption } \\
(9 \times \mathrm{AER})\end{array}$ & $\begin{array}{r}\text { Sorption } \\
(250 \mathrm{ppm})\end{array}$ \\
\hline 1 & $270 \pm 16$ & $874 \pm 2$ \\
\hline 2 & $180 \pm 15$ & $1373 \pm 7$ \\
\hline 11 & $123 \pm 3$ & $545 \pm 19$ \\
\hline 13 & $278 \pm 6$ & $1026 \pm 26$ \\
\hline 19 & $159 \pm 4$ & $424 \pm 6$ \\
\hline 30 & $176 \pm 3$ & $370 \pm 10$ \\
\hline 31 & $120 \pm 4$ & $500 \pm 2$ \\
\hline 33 & $236 \pm 11$ & $348 \pm 11$ \\
\hline 48 & $81 \pm 8$ & $546 \pm 2$ \\
\hline 54 & $167 \pm 4$ & $333 \pm 29$ \\
\hline
\end{tabular}

Mean \pm range, $N=2$

$\mathrm{AER}=$ anion exchange resin

assumed to involve desorption of $\mathrm{P}$ from oxide surfaces that were highly P-depleted, showing a strong tendency to retain $\mathrm{P}$ and compete for desorbable $\mathrm{P}$ with the AER. The initial fast desorption reaction typically slowed down after 66 $\mathrm{h}$ of sequential AER extraction and turned into a slow reaction phase after $114 \mathrm{~h}$ of extraction. After extraction had proceeded for longer than $282 \mathrm{~h}$, the slope of the tangent of the desorption curves was clearly more gentle than it had been during the initial rapid desorption phase (1 to 18 $\mathrm{h}$ of extraction). The total amount of desorbable $\mathrm{P}$ seemed to be less than the $\mathrm{P}$ sorption affected by the texture of the soils (Table 2).

We estimated the maximum sorption of labile $\mathrm{P}$ on the surfaces of active $\mathrm{Al}$ and Fe oxides $\left(Q_{\max }\right.$, Table 3$)$ by summing the amounts of native soil $\mathrm{P}$ desorbed during the nine sequential AER extractions and the sorption of $\mathrm{P}$ from the solution containing $250 \mathrm{ppm}$ of added $\mathrm{P}$ (Table 2). We then calculated the correction for 'active' $\mathrm{Al}_{\text {ox }}$ and $\mathrm{Fe}_{\text {ox }}(\alpha)$ by dividing $\mathrm{Q}_{\text {max }}$ by the sum of oxalate extractable $\mathrm{Al}$ and $\mathrm{Fe}$ (Table 3 ). The correction factor ranged from 0.09 to 0.12 , the average being $\alpha=0.11$. Even though AER cannot extract all $\mathrm{P}$ from $\mathrm{Al}$ and $\mathrm{Fe}$ oxide surfaces at low $\mathrm{P}$ saturation, $\mathrm{P}$ sorption by Al-
QS and Fe-QS shaken in solutions containing 250 ppm P suggested fairly similar $\alpha$ values for the soils studied:

\begin{tabular}{|c|c|c|c|c|}
\hline & $\mathrm{Al}$ & & $\mathrm{P}(250)_{\text {sorption }}$ & $\alpha$ \\
\hline Al-QS & 165 & 0 & 18.6 & 0.11 \\
\hline $\mathrm{Fe}-\mathrm{QS}$ & 0 & 62 & 8.4 & 0.14 \\
\hline
\end{tabular}

There was no exchangeable or dissolved $\mathrm{Ca}$ present when Al-QS and Fe-QS were shaken in $P$ solution. Because the $\alpha$-values were very similar for both pure oxides and the experimental soils, we assumed that precipitation of P-bearing Ca compounds did not greatly influence the estimated value of $\alpha$.

Most of the extractable inorganic $\mathrm{P}$ in the soils studied was in $\mathrm{NaOH}$ - or $\mathrm{H}_{2} \mathrm{SO}_{4}$-extractable form (Table 4), assumed to represent Febound or apatitic $\mathrm{P}$, respectively. Soil 54 was an exception, having more $\mathrm{NH}_{4} \mathrm{~F}$-extractable $\mathrm{P}$ (Al$\mathrm{P})$ than any other $\mathrm{P}$ fraction. In the clayey soils (numbers 1-19), the concentration of AER-extractable $\mathrm{P}$ (the sum of the nine sequential extractions) was somewhat higher than that of $\mathrm{NH}_{4}$ F-extractable $\mathrm{P}$ (cumulative AER-P being about $100-140 \%$ of $\mathrm{NH}_{4} \mathrm{~F}-\mathrm{P}$ ), while the opposite applied to the more coarse-textured soils (AER-P being $47-91 \%$ of $\mathrm{NH}_{4} \mathrm{~F}-\mathrm{P}$ ). The $\mathrm{NH}_{4} \mathrm{Cl}$ solution extracted $\mathrm{P}$ from only three out of the ten soils, and even in these (soils 33, 48 and 54) the amount extracted was less than $2 \mathrm{mg} / \mathrm{kg}$ (as compared to $170-350 \mathrm{mg} / \mathrm{kg}$ in each of the other fractions). $\mathrm{NH}_{4} \mathrm{Cl}$-extractable $\mathrm{P}$ is therefore omitted from Table 4. On average, 35\% (range $16-53 \%$ ) of the fractionable inorganic $\mathrm{P}$ was apatitic. Note that the amount of $\mathrm{P}$ extracted by oxalate was equal to the sum of the inorganic $\mathrm{P}$ fractions (Table 4).

\section{Discussion}

Oxalate overestimated the labile $\mathrm{P}$ in the soils studied. The essentially equal amounts of oxalate-extractable $\mathrm{P}$ and the sum of the inor- 
Vol. 9 (2000): 61-70.

Table 3. Oxalate-extractable aluminium $\left(\mathrm{Al}_{\mathrm{ox}}\right)$, and iron $\left(\mathrm{Fe}_{\mathrm{ox}}\right)$, maximum $\mathrm{P}$ sorption capacity of the soils $\left(\mathrm{Q}_{\max }\right.$; i.e. the amount of $\mathrm{P}$ desorbed from soils plus that sorbed by soils, from Table 2$)$, and the correction factor for "active" $\mathrm{Al}$ and $\mathrm{Fe}(\alpha)$ calculated for these soils .

\begin{tabular}{|c|c|c|c|c|}
\hline $\begin{array}{l}\text { Soil } \\
\text { number }\end{array}$ & $\mathrm{Al}_{\mathrm{ox}}$ & $\mathrm{Fe}_{\text {ox }}$ & $\mathrm{Q}_{\max }$ & $\begin{array}{c}\alpha= \\
\mathrm{Q}_{\max } /\left(\mathrm{Al}_{\mathrm{ox}}+\mathrm{Fe}_{\mathrm{ox}}\right)\end{array}$ \\
\hline & & $\mathrm{nmol} / \mathrm{kg}-$ & & \\
\hline 1 & $120 \pm 5$ & $182 \pm 3$ & 36.9 & 0.12 \\
\hline 2 & $224 \pm 6$ & $240 \pm 4$ & 50.1 & 0.11 \\
\hline 11 & $84 \pm 2$ & $131 \pm 7$ & 21.6 & 0.10 \\
\hline 13 & $117 \pm 3$ & $291 \pm 4$ & 42.1 & 0.10 \\
\hline 19 & $65 \pm 3$ & $90 \pm 3$ & 18.8 & 0.12 \\
\hline 30 & $60 \pm 4$ & $117 \pm 1$ & 17.6 & 0.10 \\
\hline 31 & $60 \pm 2$ & $118 \pm 4$ & 20.0 & 0.11 \\
\hline 33 & $65 \pm 3$ & $132 \pm 7$ & 18.8 & 0.10 \\
\hline 48 & $153 \pm 4$ & $86 \pm 5$ & 20.3 & 0.09 \\
\hline 54 & $86 \pm 6$ & $56 \pm 4$ & 16.2 & 0.11 \\
\hline
\end{tabular}

Measured values given as mean \pm range, $N=2$

Table 4. Chang \& Jackson inorganic phosphorus (P) fractions $\left(\mathrm{NH}_{4} \mathrm{~F}-\mathrm{P}, \mathrm{NaOH}-\mathrm{P}\right.$ and $\left.\mathrm{H}_{2} \mathrm{SO}_{4}-\mathrm{P}\right)$, the sum of fractionable inorganic $\mathrm{P}(\mathrm{SUM})$, and oxalate-extractable $\mathrm{P}\left(\mathrm{P}_{\text {ox }}\right)$ in the soil samples studied (mean $\pm \mathrm{SD}$ )

\begin{tabular}{clllcc}
\hline $\begin{array}{l}\text { Sample } \\
\text { number }\end{array}$ & $\mathrm{NH}_{4} \mathrm{~F}-\mathrm{P}$ & $\mathrm{NaOH}-\mathrm{P}$ & $\mathrm{H}_{2} \mathrm{SO}_{4}-\mathrm{P}$ & $\mathrm{SUM}$ & $\mathrm{P}_{\text {ox }}$ \\
\hline & & & $\mathrm{mg} / \mathrm{kg}$ & & \\
\cline { 2 - 5 } 1 & $232 \pm 12$ & $413 \pm 6$ & $261 \pm 23$ & $906 \pm 15$ & $869 \pm 17$ \\
2 & $169 \pm 1$ & $358 \pm 12$ & $100 \pm 10$ & $627 \pm 10$ & $641 \pm 12$ \\
11 & $118 \pm 4$ & $198 \pm 5$ & $238 \pm 31$ & $554 \pm 23$ & $550 \pm 4$ \\
13 & $195 \pm 1$ & $575 \pm 49$ & $243 \pm 6$ & $1012 \pm 45$ & $1093 \pm 4$ \\
19 & $136 \pm 1$ & $161 \pm 1$ & $328 \pm 68$ & $625 \pm 68$ & $612 \pm 4$ \\
30 & $194 \pm 1$ & $288 \pm 16$ & $420 \pm 8$ & $902 \pm 24$ & $847 \pm 19$ \\
31 & $144 \pm 1$ & $222 \pm 16$ & $154 \pm 3$ & $520 \pm 14$ & $560 \pm 12$ \\
33 & $261 \pm 0$ & $348 \pm 8$ & $366 \pm 52$ & $974 \pm 59$ & $1125 \pm 64$ \\
48 & $173 \pm 2$ & $180 \pm 3$ & $189 \pm 21$ & $542 \pm 22$ & $489 \pm 5$ \\
54 & $284 \pm 16$ & $160 \pm 10$ & $219 \pm 18$ & $663 \pm 22$ & $637 \pm 6$ \\
\hline
\end{tabular}

For Chang-Jackson $\mathrm{P}$ fractions, $N=3$; for $\mathrm{P}_{\mathrm{ox}}, N=2$

ganic $\mathrm{P}$ fractions show that oxalate extraction estimates "total inorganic P" rather than the P pool relevant in environmental risk assessment. Our results thus confirm that oxalate is capable of removing fairly stable soil $\mathrm{P}$, as discussed by Hartikainen (1979). The amount of fractionable inorganic $\mathrm{P}$, as well as the proportion of apatitic $\mathrm{P}$ in it, was similar in our samples to that reported in other Finnish studies (Hartikainen 1979,
Yli-Halla et al. 1995, Jaakkola et al. 1997, Turtola and Yli-Halla 1999). Due to the significant contribution of apatitic $\mathrm{P}$, the use of a single oxalate extraction is not well suited for assessing PS in Finnish soils. A combination of Chang \& Jackson fractioning $\left(\mathrm{NH}_{4} \mathrm{~F}\right.$ and $\mathrm{NaOH}$ extractions) and oxalate extraction (Turtola and YliHalla 1999) probably results in a more correct estimate because apatitic $\mathrm{P}$ is omitted. 
Uusitalo, R. \& Tuhkanen, H.-R. Phosphorus saturation of Finnish soils

In this study, we extracted roughly the same amounts of $\mathrm{P}$ with sequential AER extractions and with $\mathrm{NH}_{4} \mathrm{~F}$ solution. Hartikainen (1982) found a close correlation between water-extractable $\mathrm{P}$ (1:60 soil-to-water) and the $\mathrm{NH}_{4} \mathrm{~F}-\mathrm{P} / \mathrm{Al}_{\text {ox }}$ ratio, whereas the correlation with $\mathrm{NaOH}-\mathrm{P} / \mathrm{Fe}_{\text {ox }}$ was rather poor. She concluded that soluble $\mathrm{P}$ might be primarily controlled by Al (hydr)oxides, although Fe (hydr)oxides also participate in the process. This seems to hold for AER-extractable $\mathrm{P}$ as well, because in the present study AER-P exceeded $\mathrm{NH}_{4} \mathrm{~F}-\mathrm{P}$ in the non-clay soils. If we suppose that $\mathrm{Al}$ oxides are the most important controllers of the runoff $\mathrm{P}$ concentration, then it might be enough simply to determine $\mathrm{NH}_{4} \mathrm{~F}-\mathrm{P}$ and $\mathrm{Al}_{\text {ox }}$ when setting guidelines for soils at high risk of $\mathrm{P}$ leaching.

Lookman et al. (1995) found much lower concentrations of oxalate-extractable $\mathrm{Al}$ and $\mathrm{Fe}$ in a large material (over 300 samples) of Belgian soils than we did in the ten Finnish soil samples studied here. Lookman et al. (1995) reported that average extractable $\mathrm{Al}$ and $\mathrm{Fe}$ were less than 50 and $25 \mathrm{mmol} / \mathrm{kg}$, respectively, which is lower than for any of the soils we studied, the coarse-textured ones included. Due to the longer time it has taken soils to form in Belgium, their $\mathrm{Al}$ and $\mathrm{Fe}$ are likely to have a more ordered crystalline structure form. The less ordered crystalline form of $\mathrm{Al}$ and $\mathrm{Fe}$ oxides in Finnish soils implies that the $\mathrm{P}$ sorption capacity is higher, and that $\mathrm{P}$ is thus probably more strongly retained by Finnish soils.

The soils and the synthetic Al and Fe oxide materials used here, however, suggest a lower value (between 0.09 and 0.14 ) for the correction term $(\alpha)$ for "active" $\mathrm{Al}$ and Fe than that used in The Netherlands and Belgium $(\alpha=0.5)$. This is a controversial finding, because the $\alpha$-term should be higher for soils with higher $\mathrm{P}$ retention capacity. Since our estimate is based on depletion of desorbable P by AER and short-term sorption studies (not oxalate-extractable $\mathrm{P}$ and sorption of $\mathrm{P}$ during long incubation), the difference in estimates is attributed largely to the methods we used in our study. Because the labile $\mathrm{P}$ pool is the primary source of $\mathrm{P}$ that may dissolve in soil solution and runoff water, we tried to avoid including sparsely soluble apatitic $\mathrm{P}$ and diffusion-controlled migration of $\mathrm{P}$ into $\mathrm{Al}$ and $\mathrm{Fe}$ oxide structures when estimating $\mathrm{Q}_{\max }$. Slowly releasable $\mathrm{P}$ reserves are hardly important for the $\mathrm{P}$ dissolving during a runoff event, even though they can be a long-term source of plant-available P.

Determination of the correction factor $\alpha$ by sorption and desorption studies is not, however, without uncertainties. At low P saturation, $\mathrm{P}$ is likely to be resorbed by soil with a vast amount of unoccupied sorption sites, and the (hydr)oxide surfaces may still have some degree of P saturation despite continuous removal by, say, AER. Moreover, sorption does not reach equilibrium during $2 \mathrm{~h}$ of shaking, and we cannot claim that all surface sorption sites were filled up with P. On the other hand, the surfaces of $\mathrm{Al}$ and Fe oxides are assumed to respond to changes in ambient solution within minutes or hours (Froelich 1988). High P concentrations may also result in supersaturation in relation to some P-bearing compounds that are not thermodynamically feasible in soils, resulting in the formation of $\mathrm{P}$ precipitates and thus in overestimation of $\mathrm{P}$ sorption. Precipitation was presumably of minor importance here, as suggested by the similar $\alpha$-values for soils and pure oxides.

Knowledge of the concentrations of the $\mathrm{P}$-sorbing compounds is as important as are the soil test $\mathrm{P}$ values when seeking to assess an environmental risk. To be able to tell whether a soil has high or low P saturation, we should be able to extract $\mathrm{P}$ selectively from defined phases or compounds, as well as $\mathrm{Al}$ and Fe from (hydr)oxides that are active in $\mathrm{P}$ retention. Further studies are therefore needed on the correction for "active" $\mathrm{Al}$ and $\mathrm{Fe}$ in Finnish soils.

Acknowledgements. We thank Dr Markku Yli-Halla for the soil samples and the background information concerning them. We also thank Ms Helena Merkkiniemi for carrying out the analytical work. The two anonymous referees are gratefully acknowledged for their valuable comments. Gillian Häkli is warmly thanked for linguistic revision. 


\section{AGRICULTURAL AND FOOD SCIENCE IN FINLAND}

Vol. 9 (2000): 61-70.

\section{References}

Chang, S. C. \& Jackson, M. L. 1957. Fractionation of soil phosphorus. Soil Science 84: 133-144.

Froelich, P. N. 1988. Kinetic control of dissolved phosphate in natural rivers and estuaries: a primer on the phosphate buffer mechanism. Limnology and Oceanography 33: 649-668.

Hartikainen, H. 1979. Phosphorus and its reactions in terrestrial soils and lake sediments. Journal of the Scientific Agricultural Society of Finland 51: 537-625.

- 1982. Water soluble phosphorus in Finnish mineral soils and its dependence on soil properties. Journal of the Scientific Agricultural Society of Finland 54: 89-98.

Jaakkola, A., Hartikainen, H. \& Lemola, R. 1997. Effect of fertilization on soil phosphorus in a long-term field experiment in southern Finland. Agricultural and Food Science in Finland 6: 313-322.

Kuo, S. 1996. Phosphorus. Extraction with buffered alkaline solution. In: Sparks, D.L. (ed.). Methods of soil analysis: Part 3-Chemical methods. Soil Science Society of America, Madison, Wisconsin, USA. p. 895-897.

Lookman, R., Vandeweert, N., Merckx, R. \& Vlassak, K. 1995. Geostatical assessment of the regional distribution of phosphate sorption capacity parameters $\left(\mathrm{Fe}_{\mathrm{ox}}\right.$ and $\left.\mathrm{Al}_{\mathrm{ox}}\right)$ in northern Belgium. Geoderma 66: 285-296.

Lopez-Hernandez, I.D. \& Burnham, C. P. 1974. The covariance of phosphate sorption with other soil properties in some British and tropical soils. Journal of Soil Science 25: 196-206.
Mattingly, G.E.G. 1975. Labile phosphate in soils. Soil Science 119: 369-375.

Murphy, J. \& Riley, J. P. 1962. A modified single solution method for the determination of phosphate in natural waters. Analytica Chimica Acta 27: 31-36.

Reyes, I. \& Torrent, J. 1997. Citrate-ascorbate as a highly selective extractant for poorly crystalline iron oxides. Soil Science Society of American Journal 61: 1647-1654.

Schwertmann, U. 1964. Differenzierung der Eisenoxide des Bodens durch Extraktion mit Ammoniumoxalat Lösung. Zeitschrift für Pflanzenernährung und Bodenkunde 105: 194-202.

Sibbesen, E. 1978. An investigation of the anion-exchange resin method for soil phosphate extraction. Plant and Soil 50: 305-321.

Turtola, E. \& Yli-Halla, M. 1999. Fate of phosphorus applied in slurry and mineral fertilizer: accumulation in soil and release into surface runoff water. Nutrient Cycling in Agroecosystems 55: 165-174.

Vuorinen, J. \& Mäkitie, O. 1955. The method of soil testing in use in Finland. Agrogeological Publications 63: $1-44$.

Yli-Halla, M. 1993. Plant-availability of soil and fertilizer zinc in cultivated soils of Finland. Agricultural Science in Finland 2: 197-270.

-, Sippola, J. \& Saarela, I. 1998. Increase of potential phosphorus leaching in soils with high test concentrations. Kunglige Skogs- och Lantbruksakademiens Tidskrift 137: 187-189. 
Uusitalo, R. \& Tuhkanen, H.-R. Phosphorus saturation of Finnish soils

\title{
SELOSTUS
}

\section{Alumiini- ja rautaoksidien fosforikyllästysasteen arvioiminen suomalaisista peltomaista}

\author{
Risto Uusitalo ja Hanna-Riikka Tuhkanen \\ Maatalouden tutkimuskeskus
}

Lannoituksen lisäksi maan fosforinpidätyskyky vaikuttaa kasvien käytössä olevaan ja toisaalta myös vesistöihin huuhtoutuvan fosforin määrään. Mitä enemmän fosforia on pidättävillä pinnoilla, sitä helpommin liukenevia maan fosforivarat ovat. Jos maassa on runsaasti vapaita fosforinpidätyspintoja, riski liuenneen fosforin huuhtoutumiselle on pieni. Näin ollen fosforin liukoisuutta säätelevien yhdisteiden (hydratoituneiden alumiini- ja rautaoksidien) määrä ja niiden fosforinkyllästysaste tulisi tuntea. Tässä työssä tutkittiin kymmenen erilaisen fosforitilan ja tekstuurin omaavan maanäytteen, sekä laboratoriossa valmistettujen alumiini- ja rautaoksidien avulla miten Hollannissa ja Belgiassa käytetty tapa määrit- tää fosforin kyllästysaste happamalla oksalaattiuutolla soveltuu suomalaisille maille. Määrittämällä eri epäorgaanisiin yhdisteisiin sitoutunut fosfori voitiin todeta, että happaman oksalaattiliuos liuottaa maasta myös niukkaliukoista apatiittista fosforia ja antaa siten virheellisen kuvan alumiinin ja raudan oksideihin pidättyneen fosforin määrästä. Koska suomalaisissa maissa saattaa olla hyvinkin runsaasti apatiittista fosforia, oksalaattiuutteesta mitattua fosforia ei tulisi käyttää kyllästysasteen laskemiseen. Koska fosforin kyllästysaste on lannoituksen täsmentämisen kannalta tärkeä suure, tulisi sen määritykseen kehittää rutiinimäärityksiin soveltuva luotettava testi. 